\title{
(息)
}

Citation:

Spracklen, K (2013) Nazi Punks Folk Off: Leisure, Nationalism, Cultural Identity and the Consumption of Metal and Folk Music. Leisure Studies, 32 (4). 415 - 425. ISSN 0261-4367 DOI: https://doi.org/10.1080/02614367.2012.674152

Link to Leeds Beckett Repository record:

https://eprints.leedsbeckett.ac.uk/id/eprint/216/

Document Version:

Article (Accepted Version)

The aim of the Leeds Beckett Repository is to provide open access to our research, as required by funder policies and permitted by publishers and copyright law.

The Leeds Beckett repository holds a wide range of publications, each of which has been checked for copyright and the relevant embargo period has been applied by the Research Services team.

We operate on a standard take-down policy. If you are the author or publisher of an output and you would like it removed from the repository, please contact us and we will investigate on a case-by-case basis.

Each thesis in the repository has been cleared where necessary by the author for third party copyright. If you would like a thesis to be removed from the repository or believe there is an issue with copyright, please contact us on openaccess@leedsbeckett.ac.uk and we will investigate on a case-by-case basis. 


\section{Nazi Punks Folk Off: Leisure, Nationalism, Cultural Identity and the Consumption of Metal and Folk Music}

\section{Introduction}

Nazi Punks, Nazi Punks, Nazi Punks, Fuck Off

Nazi Punks, Nazi Punks, Nazi Punks, Fuck Off

You'll be the first to go, you'll be the first to go, you'll be the first to go

Unless you think

('Nazi Punks Fuck Off', from In God We Trust Inc., Dead Kennedys, Alternative Tentacles, 1981)

In the 1980s, far-right activists attempted to infiltrate the punk scene in the UK and other western countries with varying degrees of success: a white supremacist counterculture emerged around bands such as Skrewdriver (Brown, 2004), but mainstream punks successfully rejected the far-right's intrusion onto their alternative, individualist, left-leaning music scene (Ward, 1996). This paper explores attempts by neo-Nazis and others influenced by far-right political ideologies to express their politics through the creation and consumption of two other forms of popular music: the extreme version of heavy metal called black metal, - which was popularised in the 1990s following a series of Church burnings and murders in Norway (Kahn-Harris, 2007) - and English folk music. In discussing the construction of whiteness, the infiltration of far-right ideologies and activists, and the construction of social identity in these music scenes, I will reference a third form of popular music that bridges the gap between black metal and English folk: Neo-Folk, an off-shoot of the goth and post-punk genres, which has had a long association with taboo-breaking and flirtations with extremism. Following Spracklen (2009, 2011b) I will use Habermas' (1984, 1987) framework of 
communicative and instrumental rationality to identify and explain the extent to which each scene has resisted infiltration from the far-right.

The reason for comparing the scenes is both have attracted the interest of far-right activists. Black metal is a form of extreme metal typified by evil sounds and elitist ideologies: many bands draw on nationalist and fascist images and themes. English folk attempts to preserve and construct a national music for England, rooted in a mythicised past. Both music scenes are therefore attractive to far-right activists and ideologues seeking to use each music scene as a site of political action and commentary. Both scenes attract different far-right activists interested in the diverse range of symbols and ideologies each scene presents (English folk music is attractive to English nationalists downplaying their racism, Satanic black metal appeals to fascists interested in Crowley), but there are important points of contact between them. In the past fifteen years, some nationalist black metal bands such as Drudkh (from the Ukraine) and Forefather (from England) have taken an interest in folk music, inspired by the Neo-Folk scene and nationalist ideologies to seek 'authentic' national roots in folk music. From black metal to English folk via Neo-Folk is not as strange as it may first appear. Far-right activists drawn to black metal as angry teenagers, then, are likely to follow the trajectory of their favourite bands. As I will show, labels that sign black metal, Neo-Folk and 'dark' English folk acts have appeared to meet the demand for music with elitist symbolism and lyrical content.

Black metal and its culture of extreme ideologies has been the subject of sustained critical analysis (Beckwith, 2002; D’Amico, 2009; Harris, 2000; Kahn-Harris, 2007; LeVine, 2009; Lucas, Deeks and Spracklen, 2011; Spracklen, 2006, 2009, 2010a, 2010b; Vestel, 1999). In this paper, previous research (Spracklen, 2006, 2009, 2010a) and new research into the discourses about black metal on an internet forum will be examined alongside ethnographic reflections and unstructured interviews to explore the tensions between black 
metal as a neo-tribe and black metal as a site of the construction of whiteness and white (racist, Aryan, heathen) identity. As an insider in the black metal scene, I use my knowledge to observe discussions on a black metal on-line forum about what it means to be a fan (being 'kult' or 'true').

English folk music has been the subject of similar research into its association with authenticity, purity, tradition and nationalism (Harker, 1985; Boyes, 1993; Sweers, 2005; Gregory, 2009; Yarwood and Charlton, 2009). In this paper, I present research on English folk music that has been collected in the same way as the published research on on-line communities of black metal fans (Spracklen, 2006, 2010a, 2010b, 2011a). Observation of online forum debates about English folk music and the far-right will be utilised including debates on a folk music forum about links between neo-Nazis and a neo-folk label. In identifying the tensions between playful belonging and elitist ideology, it will be suggested that in black metal and in English folk an imagined, white community is being created that resists notions of postmodernity, globalisation and instrumental consumption. Before the discussion and analysis, however, it is necessary to situate the research in a theoretical framework, and to provide some account of methods.

\section{Theories of Leisure and Whiteness}

This research is grounded in leisure theory, and in particular the work of Spracklen (2009, 2011) in applying a Habermasian framework of communicative and instrumental rationalities and actions to understanding the tensions between utopian theories of individualised, postmodern leisure (Blackshaw, 2010; Rojek, 2010) and dystopian theories of increasing constraint and control (Bramham, 2006). At the same time, researchers of popular music have theorised the development of neo-tribes as the effect of postmodernity on practices of consumption and identity formation (Bennett, 2006; Hodkinson, 2002). Habermas (1984) 
says communicative rationality leads to the establishment of the public sphere, in which our leisure choices help us construct civic (and civil) society. In modernity, each of us belongs to the lifeworld, that part of modern life that emerges from the public sphere. All of us have the education and the reasoning to be able to think for ourselves, to construct with others a mutually beneficial world for our culture and society to thrive. What counts is the level of freedom such activities provide us, and the level of flexibility to change and adapt those activities to suit our decisions and deliberations. Being able to think for ourselves, being able to find solace in leisure, to be able to choose to make our own meaning from leisure, these are fundamental markers of humanity. But that lifeworld is in danger from the approaches of instrumental structures and organizations - the State, bureaucratization, commodification, hegemonic capitalist power, and globalisation - that threaten to colonize the lifeworld and destroy it altogether (Habermas, 1987; Spracklen, 2009). What I am interested in here is the way in which leisure choices in consuming black metal and English folk music are used to construct exclusive, white identities - whiteness associated with individualism and elitism in the case of metal, and whiteness as a product of Englishness in folk. I am interested in the 'beating of the boundaries’ (Cohen, 1985; Appelrouth, 2011) - who is allowed to define belonging in the black metal scene and in the English folk scene.

Whiteness throughout this paper is used to represent a particular, hegemonic but invisible power relation that privileges (and normalises) the culture and position of white people (Daynes and Lee, 2008; Dyer, 1997; Garner, 2006; Gilroy, 2000; Long and Hylton, 2002). The whiteness of white people can never be essentialised - there is no such thing as a white race and there is no such thing as a black race (Daynes and Lee, 2008). However, blackness and whiteness, the agency of choosing to identify with one or the other, and the instrumentality of defining those who do not belong as one or the other (the Other, as it were), are part of what Daynes and Lee (2008) call the 'racial ensemble', tools used in 
boundary work, the formation of cultural capital (Bourdieu, 1986) through communicative agency and instrumentalised consumption. Where whiteness differs from blackness is in its link to the dominant side in historical inequalities of power and the useful instrumentality of universalising white cultural norms as universal norms. Because whiteness is so privileged, Fanon (1967) argues that blackness becomes marginalised, and black people who try to become part of the mainstream are forced to adopt a 'white mask' to be accepted. In leisure, blackness is inevitably Othered as exotic, and the whiteness of everyday leisure forms is made invisible (Hylton, 2009; Long and Hylton, 2002; Long and Spracklen, 2010).

\section{Methods}

In this paper, I utilise the methodological tools of Discourse Tracing (Le Greco and Tracey, 2009) to analyse on-line and in-print debates about identity, community and the two music genres of black metal and English folk. Discourse Tracing involves the messy capture of disparate qualitative data and auto-ethnographic reflections, and drawing from the analysis the traces of dominant discourses. The data from interviews and on-line debates about black metal was collected in previously published work (Lucas et al., 2011; Spracklen, 2006, 2009, 2010a). The data collected about English folk music is new to this paper, as is the comparative analysis between the two and the ethnographic reflections across both scenes: as a middle-aged, long-haired white man with a Viking beard I can easily fit in to both a metal gig and a folk concert. Spracklen (2006, 2010a, 2010b) used the on-line forum at blackmetal.co.uk to collect data over three twelve-month periods. Opinions posted by members of the forum in the public areas of the forum were examined and searches undertaken to identify relevant threads and posts that discussed extreme ideologies. The researcher lurked but did not interact with any posters, publicly or privately. 
In the data collection on English folk music, my familiarity with the scene led me to the web-site of fRoots magazine, and its publicly accessible forum. Following the same approach as Spracklen (2006, 2010a, 2010b) I lurked on the forum for eighteen months between October 2009 and March 2011 (a period including the General Election in the UK, when the British National Party [BNP] was attempting to mobilise support to win a first seat in the House of Commons - see Rhodes, 2011), noting the number of threads relevant to this paper and collecting the postings made (sometimes going back in time before I started the research) about the infiltration of English folk by the far-right, the launch of the campaign Folk Against Fascism, and the particular case of neo-Folk. In total, 39, 030 words were collected and analysed across ten substantial threads, with an uncounted number of other threads sampled. The substantial threads were identified as important places where fans and musicians involved in English folk could express opinions about issues associated with the intrusion of the far-right.

Alongside this on-line data capture, my ethnographic reflections and reading of the two scenes' print literature then triangulated the debates through the Discourse Tracing approach: finding patterns, significances, myths, symbols and narratives in different discourses about black metal and English folk music.

\section{Black Metal - Previous and New Research}

Previous research has explored black metal as a Habermasian communicative action in the wider metal scene (Spracklen, 2006, 2009, 2010a, 2010b, 2011a). The black metal scene is clearly historically associated with whiteness (Aryan, Nordic, European) and heteronormative masculinity. It is also a globalised, globalising scene, with bands and fans across the world (Harris, 2000; LeVine, 2009). Black metal is a genre associated with a particular sound, image and ideology: 'evil' tritones and dissonances; corpsepaint, spikes, forests, snow, 
Satanic symbols, heteronormativity (Spracklen, 2010b); and individualism expressed through Satanism, nationalism, misanthropy, or heathenism.

Fans on the forum on-line make a distinction between the sound and the ideologies present (Spracklen, 2006, 2010a): they claim to be able to appreciate the music for its aesthetic or emotional qualities, while ignoring or distancing themselves from the extreme ideologies of the lyrics and imagery. This distancing is reflected in the research with black metal fans undertaken by Lucas et al. (2011) and Kahn-Harris (2007): fans claim to enjoy the music while expressing a commitment to a vaguely libertarian philosophy of allowing musicians to be free to express their disdain for the modern world in whatever ideology they wish. For the black metal fans in Lucas et al. (2011) this freedom is linked to the wider metal scene's embrace of individualism and resistance against the corporate mainstream. None of the fans in this previous work identified politically with the far right or with Satanism, beyond the playful embrace of Satanic symbols and the wearing of Thor's Hammers (appropriated by the far-right but also genuine expressions of neo-heathenism: see Von Helden, 2010). My own unstructured interviews with fans and scene insider reflections for this paper suggest an absence of organised neo-Nazi involvement. Some bands and labels are associated with National Socialist Black Metal (NSBM) or far-right/neo-Nazi ideologies, or more obscure white/ethnic supremacism. Like the fans in Lucas et al. (forthcoming) my fans were comfortable buying music from labels that champion a range of far-right politics through the absolute libertarianism to radical conservatism.

Controversy is crucial to establishing boundaries in black metal between it and the shocked mainstream. Varg Vikernes of Burzum, for example, has continued to express farright, white supremacist opinions, despite serving many years in a Norwegian prison for the murder of his fellow black metaller Euronymous of Mayhem (Spracklen, 2006). The fans I spoke to were also aware of the controversy over English black metal band Winterfylleth, a 
band that flirts with the imagery and ideology of conservatism and English nationalism. One of its members openly posted racist comments on the web and was sacked for it (Lucas, 2010), but the band has continued to describe itself as 'English Heritage Black Metal' and to declare the need to defend Englishness (Lucas et al., 2011). Winterfylleth secured a record deal with a big independent metal label after the controversy and appeared on the front cover of both extreme metal monthly magazines. Ironically, then, the Habermasian freedom of choosing to be controversial through embracing the communicative ideologies of black metal helped this band join the instrumentalised, commercialised music industry.

This flirtation with fascism in black metal is not unique in rock music. Neo-Folk emerged in the 1980s from the post-punk, industrial, goth scene. Bands such as Death in June and Sol Invictus adopted fascist themes and imagery, and played with the notion of supremacy in a seemingly ironic way (Shekhovstov, 2009). The Neo-Folk scene has continued to be a small countercultural moment, embracing paganism on the one hand and anarchism on the other, but at its core remain bands that are still associated with individuals with links to or histories of involvement in far-right politics: HERR, for example, have as a singer Troy Southgate, over the years an activist in many far-right groups including the National Revolutionary Faction (Macklin, 2005). The black metal fans on the forum and in my research are aware of Neo-Folk and many enjoy buying it and listening to it - and the monthly extreme metal magazine Zero Tolerance has regular reviews of Neo-Folk bands.

Spracklen (2010a) explored the postings on the blackmetal.co.uk forum in 2007 to examine the extreme ideologies of the scene. National Socialism is one of the four extreme ideologies associated by the fans on the forum with black metal - as a sub-genre, it has its own bands, and draws on the flirtation with fascism, white supremacy and anti-semitism expressed by bands like Darkthrone in the early 1990s. Some bands such as Hate Forest are (or were in that band's case) explicitly associated with National Socialist Black Metal and 
far-right posturing and campaigning. Spracklen (2010a: 87) discusses a poll on the blackmetal.co.uk forum assessing posters' approval of an association with NSBM:

On 10 July 2007, after just under a month of discussions, and after the heated arguments had faded away, the poll showed a majority of the black metal fans agreeing with the statement that National Socialist ideology in black metal was stupid: $54 \%$ of respondents (31 where $n=57$ ). Only $16 \%$ believed that the ideology was 'great', seemingly approving of the music and its ideology; 14\% believed NSBM was 'entertaining', a more ambivalent position to take; and 11\% said that black metal was 'supposed to be bad', apparently supporting NSBM as an extension of the provocative nature of the scene. In addition, a further 5\% believed that NSBM was 'just a bit of fun'. This on-line poll, while clearly not representative of all black metal fans, was reflective of the ambiguity of NSBM in the wider scene, and perhaps the majorityheld opinion of NSBM as something that is a provocation too far. It is also instructive to see that the people who did see a place for NSBM in black metal were not automatically in accord with its white (racist, Aryan, heathen) supremacist, romantic nationalist politics: the $11 \%$ who saw in it an extension of provocation and anticonformity; and the 5\% who saw NSBM as a big joke on the anti-NSBM fans who took it all too seriously.

For black metal fans, the essence of being a fan, in the imaginary and imagined community of black metal, is about a conscious, communicative decision to reject the instrumentality of pop and rock music. Following Habermas (1984, 1987), we can see that the elitism in the scene represents a communicative discourse: marginalising nationalism and fascism is more to do with the individualism and misanthropy of the scene rather than liberal activism. Far-right ideologies come with the territory of anti-Christian, anti-modern, posturing, but a commitment to fascism and racism is seen as going against the essence of the 
scene's nihilism: if you are going to hate everything and everyone, you cannot discriminate in your hatred. Black metal is music for nihilists of all countries and cultures, with thriving scenes in every corner of the world (Kahn-Harris, 2007; LeVine, 2009). This is why a majority of the fans on the forum, and those in my research, felt fascism and racism (and the activism behind NSBM) was not inside black metal's boundaries of belonging: NSBM was inauthentic, though it was possible to like the feeling of some of the bands.

\section{English Folk Music - New Research on fRoots Magazine}

The strap line for fRoots is: 'Local music from out there'. The magazine could be imposing a view of 'out there' predicated on a notion of a set of insiders (us, the readers and the writers of the magazine) and a set of outsiders (the foreign, strange, exotic, Other). However, this does not seem to be the reading the magazine's editor intends: out there is a wave of a hand in a vague way, a directionless placing of origin. What counts are the localness, the roots, and the authentic tradition - not the actual locations. What is authentic is music that is associated with a communicative discourse (Habermas, 1984): a rejection of commerce and fashions and an insistence on live performance, tradition and interaction.

There are three dominating discourses used in the magazine and on the forum (all threads found in public section of the forum called The fRoots Letters Board). Firstly, there is a sense of an authentic folk/roots authenticity, identified in creative expression and adherence to a set of musical traditions (imagined or otherwise). In the version of authenticity championed by fRoots, it is perfectly acceptable and authentic for a musician to experiment with fusions and musical forms from other countries and cultures - so long as there is a sense of learning those musical traditions, and a spark of creativity that recognises the ingredients that make up any fusion. This discourse is related to the second discourse: the style of the magazine is musicological. Readers are expected to have some interest in, and knowledge of, 
musical styles and forms: readers are assumed to be well-educated in folk and roots, and to have a general music training that enables them to understand there are crucial differences (use of keys, scales, beats, melodies) in the way Western music (from classical to pop) is constructed and the way in which other styles of music are constructed. Thirdly, there is a scholarly discourse that allows musicians and journalists to create relationships of sounds and traditions, which in turn inform the reader of history and context. In these discourses, then, fRoots creates an authenticity for roots music out of the assumptions of authenticity in the folk scene. The part of folk music that falls into the roots definition is deemed to be communicatively authentic. All other forms fall into the commodified world of the commercial pop music industry, which operates with the instrumental rationality identified by Habermas (1984, 1987).

The first thread titled 'English Folk “Arthritically White”' was an angry debate about an article in The Guardian on what notorious politicians might have on their iPods. Part of the original article about Nick Griffin, Leader of the BNP, was posted by Ian (16 January 2010, 2.48pm). It read:

No prizes for guessing the BNP chieftain's favourite type of music. Yes, it’s that most arthritically white of genres - English folk. In particular, Griffin (who penned lyrics for an album of "patriotic" songs entitled West Wind in 2007) is a fan of nu-folk poster girls Eliza Carthy and Kate Rusby. Championing Rusby on his blog as "an alternative to the multi-cult junk played incessantly on Radio 1”, the BNP leader apparently turned up at her gigs, wanting to "do something”. Griffin's attempts to appropriate folk could be seen as an attempt to jettison the far right's association with dodgy heavy metal (see: Skrewdriver), but his efforts have met with revulsion from the folk fraternity, who have formed Folk Against Fascism in response. In the meantime, Griffin has always got the BNP's record label (Great White Records) and 
singer-songwriter Colin Auty (key track: Mr Griffin Says Hello!) to fly the BNP folkie banner instead.

Apart from the confusion about Skrewdriver (not a heavy metal band), the article was correct in identifying the BNP leader's love of English folk, which was evident in many other statements he had made. The article triggered an angry response from many of the forum posters, who insisted that folk was their music, not Griffin's, and that English folk was the product of multiculturalism and left-wing revivalism in the 1960s, exactly the modern trends Griffin and the BNP rejected. Eliza Carthy, a relatively well-known folk musician, was cited a day after the original posting (via a link to the Folk Against Fascism web-site) strongly condemning Griffin and the BNP. At the time, she was touring with the band The Imagined Village, whose music draws on a range of musical styles including reggae, bhangra and dub. I saw her with the band in Leeds, and her anger about being linked to the far-right was so intense she orchestrated and recorded ('for the next album') the audience chanting a simple but strong response telling Griffin and the fascists what we all thought of them.

What sustained the thread beyond the outrage of the BNP attempting to co-opt English folk, though, was the comment about the 'arthritically white' nature of English folk. Numerous counter examples of young folk musicians and folk fans were listed, but there were no similarly long lists identifying English folk musicians and fans from minority ethnic communities (Dogan Mehmet being the one exception mentioned). The whiteness of English folk was perceived to be a problem by a majority of the respondents, though some claimed this was because of its association with an Englishness that was rooted in a traditional past. Others who said it was not a problem argued that it was just a matter of taste. Some posters rejected the concept of Englishness altogether because of its association with nationalism and the Empire, but some equally defended Englishness and were determined to keep England's symbols such as the flag of Saint George out of the hands of the far-right. Folk fans were 
enjoying the use of Habermasian communicative reason and action: using the freedom of the scene to resist the far-right or to re-claim some of the ideas about Englishness from the farright.

In the second thread 'John Barleycorn Reborn/Coldspring/Neo-Folk', posters debated whether the magazine should have any connection with a company that had links with bands and musicians from the controversial neo-Folk scene. An independent label called Cold Spring Records (CSR) advertised in an issue of fRoots for bands to contribute to a second 'dark folk' album. Some fans on the forum questioned the editor for allowing CSR to advertise, pointing out that CSR released Neo-Folk and industrial music by bands with neoNazi associations (HERR) or neo-Nazi pasts (Sol Invictus’ front man Tony Wakeford had been a member of the National Front in the early eighties before he joined the band). Others questioned CSR and claimed it to be a 'front' for extremism. Others argued the opposite: some musicians on the forum explained they had contributed to CSR's other 'dark folk' compilation album. This thread showed the tension between the communicative freedom of the scene and the instrumentality of the industry (Habermas, 1987): some musicians saw CSR as an outlet for their own music.

'Folk Against Fascism' itself was the subject of the third thread, started by Ian on 8 June 2009, 4.06pm. The discussion started when the campaign was launched, with various links to the Folk Against Fascism web-sites, and a posting of artwork for the campaign. All the postings were supportive of the campaign, but the mood darkened when Andy Turner posted a message he had received from a morris dancer (posted 15 July 2009, 10.17pm, the message from the far-right morris dancer italicised by me, spelling mistakes in original):

Both my own and the Magpie Lane MySpace sites display “Folk Against Fascism” in our top friends. Has anyone else received a similarly badly-written and threatening 
message from http://www.myspace.com/morrismerrymaker or am I privileged in having been singled out?

Ignor the friedship request!!! I will advise everyone i know and perform with to stop buying music made by Andy Turner, Magpie Lane, Gecko or chameleon. whilst you are friends with a group who masquerade as Anti-fascist but who are infact just Anti-BNP. The British National Party introduce and encourage thousands of English folk to English folk customs, traditions and music every year. A large number of BNP members and supporters attend folk festivals and gigs up and down this country. It is possible that by remaining friends with "Folk Against Fascism" your identity could appear on "RedWatch", making public aparance less safe. You are a musician who's tallent i admire, so i was bitterly dispointed to see you affiliated such a vile ideology. People who hold dear the customs and traditions of England often in turn hold dear our Ethnic identity because witout it the other cannot exist During a conversation with John Kirkpatrick in 1998 he told me of his concern that immigration will eventually "snuff out Englishness".

RedWatch is a website identifying anti-fascists and other campaigners against the BNP, and those who work against racism or for equality more generally: it is a 'hit list' of people with contact details and has been linked to actual attacks by far-right activists against journalists and campaigners. The threat was clear enough but the musicians on the forum were keen to demonstrate they were standing up to fascism. Rather than back down, Andy Tuner and others on the forum took the opportunity to re-state their commitment to Folk Against Fascism. John Fitzpatrick also logged on and denied he had said anything about immigration and Englishness at any point. The communicative nature of the scene successfully rejected the attempt to co-opt English folk. 
‘The New Leaked BNP Membership List' thread started when the BNP's membership database was passed to Wikileaks and stories were published in the UK press about the type of people on the list, which included a semi-professional folk musician. Vic Smith (21 October 2009 12.09pm) went to Wikileaks and posted the name of a self-styled ‘pagan’ BNP member whom he recognised as performing under the name Mark Ye Morris. Other BNP members were then found on the list who expressed an interest in folk music. This solicited a response by Cav (21 October 2009, 2.47pm) who asked whether the publishing of such details was meant to prompt posters to 'kill them? Write a strongly worded letter?' Cav's questions led to a discussion about Nick Griffin’s appearance on the BBC’s Question Time and whether the BNP were a legitimate party. Some argued that there should be no platforms for racists and fascists, but others said the BNP was legitimate so the BBC had to give it a platform to express its views, however repellent.

A fifth thread on a concert celebrating the involvement of gay people in English folk ('Nowt so Queer as Folk') led to some posters questioning whether sexuality was at all relevant to English folk music. Inevitably, comparisons were made about folk fans who believed the BNP should be allowed to play English folk music at their festivals and sell it through their websites. The arguments turned from homophobia to racism, with the majority of the posters arguing against the minority about the importance of confronting the far-right. These were replicated in a sixth thread, 'Is FAF politicising folk?', where joaniecrumpet (posted 14 April 2010, 11.20am) said:

I am pretty disappointed at some conversations currently being had on the morris discussion lists. For any morris dancers who are concerned at the idea of being involved in "political" events, or who think that Folk Against Fascism should not be "politicising” folk music and dance, let's be clear: it is the BNP who are trying to politicise your music and your dance. THEY want to co-opt folk music, dance and 
culture as part of a very narrow and exclusive definition of Englishness, which suits their racist agenda. They are telling people that they are the only political party who cares about English identity, and telling their supporters that they are the only party who will protect, preserve and celebrate English traditions. That includes YOUR music and dance. If you do not want your dance to become part of that political agenda, there is a way you can voice your objection: support FAF.

In the discussion's final moments, the poster stanshall raised the history of English folk music (posted 17 April 2010, 5.17pm) and argued that:

We have to question that early collectors' version of folk, since it was spearheaded by Cecil Sharp as overtly and explicitly 'patriotic' in its aims. No wonder Griffin thinks he can hitch a ride on the latest 'folk revival'... Emphasising modern folk's multicultural influences, the mongrel heritage, the essential hyphen in Anglo-Saxon, is something that will help see off the BNP.

A seventh thread entitled 'Getting Britfolk to non-white audiences and musicians' was instigated by concerns about the whiteness of English folk and the lack of black faces in bands and at concerts. Some posters responded by saying there were cultural reasons why it was difficult to attract minority ethnic British groups to folk music. Others said it was a complete non-issue and no-one should expect any particular group of people to participate in English folk (apart from, presumably, white English people). The original poster, MurkeyChris, replied by noting (posted 14 January 2011, 6.37pm):

I can't help cringing when I take a friend to a folk event and the audience is exclusively white. It'd not something I see anywhere else in London, and whatever the reality, gives the impression that the folk scene is a rather backwards and unwelcoming place. 
The eighth thread 'Reggae Britannia' turned into a discussion about multiculturalism, popular culture and authentic music styles when the poster Andy Turner says (posted 15 February 2011, 10.17pm):

I support the idea of immigrants maintaining their language and culture (wish more indigenous English took a pride in their traditions). On the other hand, I approve of musical experimentation and integration when different cultures meet, especially if that's a two-way street... Then I also believe that all British citizens should respect British values e.g. tolerance of other races and religions. And in practice anyone living in Britain needs to have a functional grasp of the English language, whatever they choose to speak at home.

This was followed by a debate between two posters, both of whom claim to be socialists, about whether multiculturalism has worked or not in the UK. Both posters ended up saying the same thing about balancing tolerance with a commitment to liberal freedoms and human rights.

The ninth thread 'Folk music, racism and political correctness' began with the original poster asking whether it would be acceptable to publicly sing songs from the past that used offensive terminology and racialised humour, in 'today's politically-correct, racially-sensitive world?’ (Deborah Maskin, posted 15 March 2011, 5.36pm). Des Bowring responded by complaining about the musician Sheila Chandra changing the words of songs ‘that obviously offended her delicate sensibilities' (posted 15 March, 6.08pm). Bowring's concern was for the authentic nature of the folk tradition, the reproduction of songs passed down through time from the pure source of their rural English creation, a pure communicative endeavour (Habermas, 1984) - but the suspicion of non-white artists and politically correct white folk fans changing that tradition is clear. 
Fiinally, Ian Anderson, the editor and founder of the magazine, had much to say about world music in a thread started to discuss the demise of an American reggae music magazine ('The Beat RIP: world music and its lost soul', response by Ian posted 22 December 2009, $2.09 \mathrm{pm})$. His anger with the current scene was clear, and it is worth quoting at length from his posting:

As the world music scene has tried ever harder to become glossy, coffee table, and ape the corporate mainstream with its Thatcherite "fuck you, I'm only in it for myself and what I can get out of it” mentality, it has lost a lot of its soul in the process and... its sense of community and the all important symbiosis that used to make it thrive... I had a lightbulb moment recently. The generation largely in charge of the world music scene, regardless of their politics, really are Thatcher's children. They grew up - spent their teenage years - in the 1980s and those attitudes, subtly or unsubtly, infected everybody in their formative years. Whereas the folk scene had a lost generation and it coincides with that era: with exceptions of course, most folk scene people seem to be either well under 30 or well over 50 .

Anderson's comments are interesting because of his key role in the scene as an editor and publisher. His magazine supports world music artists, but he is more ambivalent about the world music scene's authenticity. It is not as authentically communicative in a Habermasian sense as the (English) folk music scene, which it overlaps. Anderson believes that the latter music genre has some connection with traditions, with roots, and with communicative actions, which make the creation and reception of folk music less instrumental than other forms of pop music. Some world music falls into this authentic folk/roots scene by nature of its relationship to 'genuine' traditions. Anderson's post attracts some criticism from a small number of posters who argue that world music does have decent people working in it who are motivated by the music and not making money. However, most 
of the posters agree with Anderson's suspicion of world music as something instrumentally ersatz. One poster, Vic Smith, makes two important contributions to the debate. In his first post, he reflects on his experience of world music gigs:

I like the majority of the people that I meet there, but there is always an element that are there to show how 'right on' they are, giving off that "Here's me doing the right thing politically. I don't give a monkey's about the music or the tradition it comes from.” (posted 22 December 2009, 11.37pm)

Across the forum there is a dominant discourse of authenticity in folk music, which is identified with boundary work: communicative actions around the meaning and purpose of musical creations, and the active engagement of fans in the establishment of folk/roots taste (Bourdieu, 1986; Prior, 2011). It is this discourse that contributes to the maintaining of the boundary between true 'roots' music (folk music) from pop. There is, politically, liberal-left scepticism of global capitalism, a desire to preserve English folk traditions but a strong rejection of English nationalism. Support of English 'trad' folk musicians is given alongside similar acclamations of support for world musicians who can demonstrate their commitment to preserving their own musical traditions and their own 'authentic voices'. That said, the posters on the fRoots forum are also supportive of English folk musicians who play with the traditions of the scene, or who embrace hybridity to create new, communicative, fusion forms of roots music: Bellowhead, who incorporate jazz and Latin American rhythms in their music, are praised for their folk grounding and their commitment to re-working traditional English folk songs; and The Imagined Village project, a multicultural clash of traditional English folk with British Asian and black British music and musicians, is similarly praised for its grounding of folk in modern Britain's diasporic hybridity (the band's name cleverly adopting the academic framework of the imagined community). 
To summarise, then, on the forum there is a clear rejection of English nationalism and far-right politics. The left ideology of the Folk Against Fascism campaign is the dominant discourse (the inclusiveness of English folk) but there is also a minority residue of nationalism and concern with the pure or authentic nature of scene (especially in morris). There is some concern by some folk fans with Englishness in the desire to preserve traditions, often in opposition to some awareness by others of the whiteness of the scene.

\section{Conclusions}

This paper makes a strong argument for ontological and epistemological connections between two seemingly separate scenes in music: it is through the politics of hegemonic whiteness and nationalism - as well as the tension between leisure and capitalism - that black metal and English folk intersect. This intersectionality creates ontological meanings of identity and authenticity that are shared by both scenes, as well epistemological debates over the rules of entry into the scenes. Both music scenes supposedly represent authentic spaces constructed by the free leisure choices of their participants, but both scenes are spaces where myths of purity and resistance to the mainstream (and resistance to modernity) become signifiers of exclusion. In the black metal and English folk music scenes we can see boundary work defining belonging, which individuals and groups are in and out of the two scenes. We can explain the boundary work using Habermas: this is communicative reason at work (Habermas, 1984, 1987), in the agency of individuals attempting to challenge the restrictions of the music industry and the globalised, corporatised leisure of today (Spracklen, 2009). Both music scenes can be understood to represent places where individual actors have space and freedom to resist commodification and to insist on their own arbiters of taste, of belonging and of exclusion (Prior, 2011). However, both music scenes are reliant on the machinery of capitalism and the discourse of industrial production: metal and folk musicians 
make records and companies sell those records to fans who find their identity through the transactions of consumption.

Such freedoms are also compromised by the hegemonic whiteness of both music scenes. Whiteness is tied up with elitism in black metal and Englishness in folk music, and both forms of whiteness make these scenes attractive to fascists and racists seeking to co-opt them. While English folk music has been quick to resist fascism co-opting its traditions, black metal is open to fascist involvement through its adherence to individualism. In both scenes, however, hybridity is rejected in favour of purity (of ideas, of traditions, of symbols of belonging and exclusion). Purity creates impermeable boundaries, which dissuade tastemakers and scene-setters from embracing hybrid forms, typified by mainstream heavy metal and the globalised pop of world music. Hybridity here is key to a critical understanding of the role of music in the construction of multiple identities, but such construction, while demonstrating the agency presupposed by Brah (1996), Solomos (1998) and others, is limited by the instrumentalised structures of Western society and the whiteness of Western national identities (Garner, 2006). This leaves black metal's true, 'kult' nature as elitist and nihilist, with the white face make-up of the corpsepaint a suggestion of the white mask of Fanon, the whiteness of the scene's mythology and history; and leaves English folk music suffering the dissonance of rejecting fascism while policing the boundaries of a mythical English village in which white people dance around a maypole.

\section{References}

Appelrouth, S. (2011) Boundaries and early jazz: Defining a new music. Cultural Sociology, 5(2), pp. 225-242. 
Beckwith, K. (2002) Black metal is for White people: Constructs of colour and identity within the extreme metal Scene. M/C: A Journal of Media and Culture, 5, published on-line at http://www.media-culture.org.au/0207/blackmetal.php.

Bennett, A. (2006) Punk's not dead: the significance of punk rock for an older generation of fans. Sociology, 40, pp. 219-35.

Blackshaw, T. (2010) Leisure. London: Routledge.

Brah, A. (1996) Cartographies of the diaspora. London: Routledge.

Bramham, P. (2006) Hard and disappearing work: making sense of the leisure project. Leisure Studies, 25(4), pp. 379-90.

Bourdieu, P. (1986) Distinction. London: Routledge.

Boyes, G. (1993) The imagined village: Culture, ideology and the English folk revival. Manchester: Manchester University Press.

Brown, T. (2004) Subcultures, pop music and politics: Skinheads and "Nazi Rock" in England and Germany. Journal of Social History, 38(1), pp. 157-78.

Cohen, A. (1985) The symbolic construction of community. London: Tavistock. 
D’Amico, G. (2009) Black metal, literature and mythology: The case of Cornelius Jakhelln. Nordicum-Mediterraneum, 4(1), pp. 25-53.

Daynes, S. \& Lee, O. (2008) Desire for race. Oxford: Oxford University Press.

Dyer. R. (1997) White. New York: Routledge.

Fanon, F. (1967) Black skin, white masks. London: Pluto.

Garner, S. (2006) The uses of whiteness: What sociologists on Europe can draw from US research on whiteness. Sociology, 40, pp. 257-75.

Gilroy, P. (2000) Between camps: Nations, culture and the allure of race. London: Allen Lane.

Gregory, D. (2009) Fakesong in an imagined village? A critique of the Harker-Boyes Thesis. Canadian Folk Song, 43(3), pp. 18-26.

Habermas, J. (1984) The Theory of communicative action, Volume One: Reason and the rationalization of society. Cambridge: Polity.

Habermas, J. (1987) The theory of communicative action, Volume Two: The critique of functionalist reason. Cambridge: Polity.

Harker, D. (1985) Fakesong: The manufacture of British folksong, 1700 to the present day. Milton Keynes: Open University Press. 
Harris, K. (2000) Roots? The relationship between the global and the local within the global extreme metal scene. Popular Music, 19(1), pp. 13-30.

Hodkinson, P. (2002) Goth: Identity, style and subculture. Oxford: Berg.

Hylton, K. (2009) ‘Race’ and sport: Critical Race Theory. London: Routledge.

Kahn-Harris, K. (2007) Extreme Metal. Oxford: Berg.

LeGreco, M. \& Tracy, S. (2009) Discourse Tracing as qualitative practice. Qualitative Inquiry, 15(9), pp. 1516-1543.

LeVine, M. (2009) Doing the Devil's work: Heavy metal and the threat to public order in the Muslim world. Social Compass, 56(4), pp. 564-76.

Long, J. \& Hylton, K. (2002) Shades of white: An examination of whiteness in sport. Leisure Studies, 16, pp. 87-103.

Long, J. \& Spracklen, K. (2010) Sport and challenges to racism. Basingstoke: Palgrave.

Lucas, C. (2010) White power, black metal and me: Reflections on composing the nation. In R. Hill and K. Spracklen (Eds.) Heavy Metal Fundametalisms: Music, Metal and Politics (pp. 43-53). Oxford: ID Press. 
Lucas, C., Deeks, M. \& Spracklen, K. (2011) Grim up north: Northern England, Northern Europe and black metal. Journal for Cultural Research, 15(3), pp. 279-95.

Macklin, G. (2005) Co-opting the counter culture: Troy Southgate and the National Revolutionary Faction. Patterns of Prejudice, 39, pp. 301-26.

Prior, N. (2011) Critique and renewal in the sociology of music: Bourdieu and beyond. Cultural Sociology, 5(1), pp. 121-38.

Rhodes, J. (2011) It's not just them, it's whites as well: Whiteness, class and BNP support. Sociology, 45(1), pp. 102-17.

Rojek, C. (2010) The labour of leisure. London: Sage.

Shekhovstov, A. (2009) Apoliteic music: Neo-Folk, martial industrial and "metapolitical fascism”. Patterns of Prejudice, 43, pp. 431-457.

Solomos, J. (1998) Beyond racism and multiculturalism. Patterns of Prejudice, 32, pp. 45-62.

Spracklen, K. (2006) Leisure, consumption and a blaze in the Northern sky: Developing an understanding of leisure at the end of modernity through the Habermasian framework of communicative and instrumental rationality. World Leisure Journal, 48(3), pp. 33-44.

Spracklen, K. (2009) The Meaning and Purpose of Leisure. Basingstoke: Palgrave. 
Spracklen, K. (2010a) True Aryan black metal: The meaning of leisure, belonging and the construction of whiteness in black metal music. In N. Scott (Ed.) The Metal Void: First Gatherings (pp. 81-93). Oxford: ID Press.

Spracklen, K. (2010b) Gorgoroth’s Gaahl’s gay! Power, gender and the communicative discourse of the black metal scene. In R. Hill and K. Spracklen (Eds.) Heavy Metal Fundametalisms: Music, Metal and Politics (pp. 89-102). Oxford: ID Press.

Spracklen, K. (2011a) Playing with madness in the forest of shadows. In C, Mackinnon, N. Scott and K. Sollee (Eds.) Can I Play with Madness? (pp. 169-76). Oxford: ID Press.

Spracklen, K. (2011b) Constructing Leisure. Basingstoke: Palgrave.

Sweers, B. (2005) Electric folk: The changing face of English traditional music. Oxford: Oxford University Press.

Vestel, V. (1999) Breakdance, red-eyed penguins, Vikings, grunge and straight rock n roll. Young: Nordic Journal of Youth Research, 7(2), pp. 4-24.

Von Helden, I. (2010) Scandinavian metal attack: The power of Northern Europe in extreme metal. In R. Hill and K. Spracklen (Eds.) Heavy Metal Fundametalisms: Music, Metal and Politics, pp. 33-41. Oxford: ID Press.

Ward, J. (1996) This is Germany! It's 1933! Appropriations of fascism in New York Punk/hardcore in the 1980s. The Journal of Popular Culture, 30, pp. 155-84. 
Yarwood, R. \& Charlton, C. (2009) Country Life? Rurality, folk music and Show of Hands. Journal of Rural Studies, 25(2), pp. 194-206. 